\title{
СОЦІАЛЬНИЙ ВПЛИВ ДУХІВНИЦТВА НА ЖИТТЯ РУСИНСЬКОГО НАСЕЛЕННЯ АМЕРИКИ НА ШПАЛЬТАХ ЧАСОПИСУ «СВОБОДА» КІНЦЯ ХІХ - ПОЧАТКУ ХХ СТ.
}

\section{Короткова Олена}

Метою дослідження є аналіз впливу католицького духівництва на сочіальне життя русинського населення в Америці через вивчення публікацій українського часопису "Свобода» $X I X$ - початку XX cm. Методологія дослідження: принципи системного наукового історизму, використання загальнонаукових методів аналізу, синтезу, узагальнення та порівняння. Наукова новизна та оригінальність полягає у детальному аналізі публікачій украйнського часопису «Свобода» в Америці XIX - початку XX ст., щуо дало можливість визначити виняткову роль католииького духівництва у формуванні сочіальних иінностей русинського народу в еміграиії, його роль у боротьбі за освіту, здоровий спосіб життя населення, національну $і$ політичну єдність, покращення умов праџі робітників і селянства, простежсти діяльність «Руського народного союзу» українців у США та Канаді. Показано, щуо найважливішим чинником соціального життя українців в еміграції була україномовна преса. Католицьке духівництво намагалося контролювати сочіальне життя «українських американців» задля збереження національних традицій, мови, поширення просвітництва, організації соціальної допомоги украӥниям та висвітлення найбільш важливих проблем емігрантів. Автори і дописувачі часопису «Свобода» закликали за прикладом інших народів (поляків, чехів, румунів) створювати народні організаиії задля підтримки підприємництва, икільництвва й освітянства, розвитку народної духовності та мови. Велика увага приділялася участі русинського народу у політичному житті, створенні клубів і культурних осередків. Головним досягненням "свободівиів» стало створення єдиного соиіально-політичного емігрантського иентру - Руського Народного Союзу. Духівництво вело боротьбу за збереження мовної ідентичності україниів. Автори постійно зверталися до проблематики мовної денацифікаиії, особливо русифікації населення. Окрім просвітництва автори часопису велику увагу приділяли аналізу епідеміологічної ситуаціі, поширення голоду, методам боротьби із захворюваннями віспою, холерою, грипом. Просвітницька робота дописувачів «Свободи» полягала і у висвітленні страшних соціальних наслідків пияцтва та нездорового способу життя украӥнців. Духівництво ставило за мету боротьбу з недоїданням і голодом, висвітлювалися статистичні дані та трагічні випадки голодних смертей серед емігрантів у різних штатах. Вагомою перевагою часопису “Свобода», на відміну від иерковних періодичних видань материкової Украӥни, стала його світська $i$ соиіальна спрямованість без перевантаження догматикою і проповідництвом.

Висновки: важливим і майже єдиним чинником суспільно-політичного життя украӥнців за кордоном у процесі національного відродження та боротьби за національну єдність та ідентичність стало католицьке духівництво.

Ключові слова: католицтво, русин, часопис «Свобода», еміграџія, соџіальний.

На зламі XIX-XX ст. важлива роль у формуванні національної ідеї та збереженні цінностей і надбань українського народу належала греко-католицькій церкві та їі духівництву. Українське греко-католицьке духовенство ставало не тільки саме релігійним осередком національної ідентичності, а й ядром формування національної інтелігенції в умовах відсутності інших вагомих чинників протистояння денацифікації [5, 9]. Щодо українців в еміграції, взагалі складно 
говорити про тодішню ситуацію в національному та соціальному становищі: роз'єднані, безпорадні, кинуті у безодню невизначеності, з єдиною метою - вижити. За неповними офіційними даними на початку XX ст. у США проживало 470 тис. українців $[2,123]$. У таких умовах головним провідником русинів-емігрантів стала саме греко-католицька церква.

На думку автора, українська католицька церква на теренах Америки і Канади на той час виконувала надважливі функції - створення національних осередків (братств, союзів), відкриття читалень, шкіл, політичних осередків, аптек, кас взаємодопомоги тощо. Одним із найважливіших чинників діяльності духівництва став випуск українських періодичних видань.

3 проблематики розвитку української преси в еміграції існує кілька вагомих досліджень першої половини ХХ ст. Найбільше заслуговують уваги науковців дослідження Ю. Бачинського та А. Животко [1; 4]. Автори окреслили головні проблеми соціального життя українського населення в умовах еміграції та висвітлення їх у відомих україномовних періодичних виданнях Америки і Канади $\mathrm{XIX}$ - початку XX ст. Сучасні науковці не залишають поза увагою вивчення проблеми розвитку української періодики на теренах Америки. Одним із найвагоміших і авторитетних дослідників сьогодення є П. Часто, який присвятив свою роботу вивченню проблем періодичної світської та релігійної преси «американської України» [19]. Л. Біловус також провів грунтовний аналіз україномовної періодики української діаспори США [2]. Розвитку української преси на американському континенті наприкінці XIX - на початку XX ст. присвятили своє дослідження О. Хімяк і С. Герегова [18; 3].

Метою статті $\epsilon$ грунтовний аналіз впливу католицького духівництва на соціальне життя русинського населення Америки через вивчення публікацій українського часопису «Свобода» XIX - початку XX ст.

Найважливішим чинником соціального життя українців в еміграції була україномовна преса. Засновниками перших і найбільш авторитетних періодичних видань українців в Америці стало греко-католицьке духівництво. Саме католицька паства робила можливе і неможливе задля збереження національних традицій, мови, поширення просвітництва, організації соціальної допомоги українцям та висвітлення найбільш важливих проблем емігрантів. Україномовні часописи «Аляска Геральд» (1868) і «Свобода» (1893) стали фундаментом розвитку української преси. Засновником і видавцем часопису «Аляска Геральд» був православний священник Агопін Гончаренко (справжнє ім'я - Гумницький Андрій Онуфрійович). Він особисто складав і редагував тексти, займався розсилкою номерів українцям Сибіру та Аляски, адресуючи їі тисячам українців - нащадків запорізьких козаків, які там проживали. Друковані органи подавали інформацію 
про події всередині країни і за кордоном, повідомляли читачів про життя українських громадських організацій, їхні плани на майбутнє, знайомили своїх читачів з історією рідного краю, його культурою та релігією $[3,98]$.

Засновником часопису «Свобода» став тернопільський священник Григорій Грушка, що служив парохом церкви Петра і Павла у Джерсі Сіті. Талановитий богослов, поет, народознавець прагнув захистити права і свободи українських американців. Саме 3 цією метою він і заснував газету «Свобода», перший номер якої о. Грушка видав 15 вересня 1893 року. Своєю метою він вважав поширення просвітництва та збереження національної мови та ідентичності. Авторами і дописувачами часописів свого часу були такі видатні історичні особистості: І. Франко, М. Грушевський, С. Петлюра, М. Павлик. Досить типовим був той факт, що більшість періодичних видань емігрантів були засновані саме священниками. Львівська Метрополія в особі Митрополита Сильвестра Сембратовича теж намагалася підтримувати тісний зв'язок із заокеанськими патріотично налаштованими священниками, всіляко сприяючи розповсюдженню видань «Свободи» на галицьких землях. Підтримка часопису була статусною справою для священництва. Кожний представник української пастви вважав за потрібне брати участь у благочинній справі - фінансовій підтримці видання, надаючи щомісяця по п’ять доларів [19, 476; 2, 54].

Часопис «Свобода» мав чітку структуру й окремі тематичні блоки: «Вєсті 3 Америки», «Вєсті зі старого краю», «Новини», «Весела хвиля» тощо. Розділ «Вєсті зі старого краю» завжди був присвячений проблемам існування русинів, ïх полонізації, труднощам роботи русинського духівництва на пригноблених землях. Наприклад, у третьому номері «Свободи» від 15 жовтня 1893 р. автор обурюється тим, що поляки скасували віденську руську семінарію як шкідливу для полонізації населення. Автор вражений тим, що русинство майже ніяк не відреагувало на таку несправедливість, закликає об'єднуватися і не мовчати «акі агнєц на закалєніє» $[7,2]$. Головною тезою авторів часопису стало єднання всіх русинів незалежно від того, де б вони не мешкали, якою б мовою не розмовляли, чим би не займалися - Канада чи Австралія, Україна чи Америка. «Тримаймося купи. Щоби людей таких вибрати до уряду, на се треба нам організацій та порозуміння єя всіх емігрантов» $[17,1]$.

У четвертому номері стаття-передовиця повністю присвячена зверненням до народу русинського щодо об'єднання зусиль у боротьбі за збереження національної і духовної ідентичності на чужинських землях. Автор закликає за прикладом інших народів (поляків, чехів, румунів) створювати народні організації задля підтримки підприємництва, шкільництва і освітянства, розвитку народної духовності та мови. «Гей, браття, вставаємо, вже і нам час статися до роботи, не 
засипляємо дорогого часу, протираємо очі і подивимося, як то другі народи, тримаючись у купі, много снопов нажали для себе...» $[8,1]$. Автор закликає «заложити організацію «Народний руський союз», котрий для робітників руських мав віткрити двері», та мав бути створений на кошти робітників і ним мали керувати саме робітники задля допомоги нужденним русинам. Однією з головних цілей цього союзу священництво бачило у закладанні читалень і вечірніх шкіл для дорослих, поширенні просвіти за допомогою «полєзних книжочок». Окрім того, велика увага повинна приділятися участі русинського народу у політичному житті - «закладанню політичних клюбів та брати живу участь у виборах». На своїх шпальтах «свободівці» пильно відслідковували створення політичних організацій в багатьох місцях. Наприклад, у шостому номері газети 1893 р. видання автор радіє, що у місті Джерсі Сіті створено політичний клуб і браттярусини отримали можливість відстоювати свої права: «наші браття-русини починають братись таки надобре до діла і познали чого їм треба, щоб мати честь їі повагу у других людей. Пару днів тому назад заложили собі політичний клюб, до котрого на перший раз досить людей вступило. Щасти, Боже, новому і першому руському клюбу!» $[9,1]$.

Соціальним «продуктом» діяльності часопису можна вважати створення єдиного соціально-політичного емігрантського центру - Руського Народного Союзу (далі РНС). РНС був заснований у містечку Шамокін штату Пенсильванія 22 лютого 1894 р. $з$ кількох місцевих братств, які залишили «Соєдінєніє греко-католицьких руських братств», не погоджуючись 3 його консервативними i проугорськими та русофільськими позиціями. Організація «Руский Народний Союз» взяв собі за мету не тільки нести порятунок від бідності, але і витягнути «русько-американський народ» 3 душевної темноти, невігластва, збудити у ньому притаманне почуття гідності вільної людини, створеної не для рабства, вказати йому дорогу до просвіти і цивілізації.

Автори часопису багато уваги приділяють дискусії щодо свободи русинів та їх прав на чужині. Головною проблемою вони вважають нездатність і небажання народу до позитивних змін. Свобода для неосвіченої і непрогресивної людини не має великої цінності. Викликає глибоке обурення небажання народу покладати зусилля до покращення життя. Автор визначає, що «якби народ руський мав повну свободу, тоді б, мабуть, весело і добре жилося, але вперед волі наш народ треба буком гнати до школи і просвіщати. Темному народові дати повну свободу означає дати малій дитині гостру бритву для забави» $[15,1]$. Головні питання, що турбують русинське духівництво, чому на вільній американській землі русин прозябає так само, як і в «старім краю»: «забобонний і вузькоглядний, за церковну свічку буде сваритись та по судах волочитись. Ощадність 
йому не знана, до участі в організаціях і товариствах неохочий і продовжує бути посміховиськом для інших». «Чи така вже наша доля - бути рабами і подноженієм у інших? Бог дав волю і розум кожному з нас, щоб ми собі могли придбати добро для душі й тіла. За то не можемо ми нарікати ні на кого, тілько на себе самих!» $[15,1]$. Автори часопису спонукали народ до активної боротьби за свої права, чесної продуктивної праці. Всі обставини життя у вільній Америці, здавалося б, дають русинам можливість широкого розвитку. Але, насправді, можна побачити зовсім інше - недбалість, пиятику, сварки тощо. Дуже рідко «посеред амерекансько-руської темноти мигне вогник, який на хвилину освітить той сум і морок».

Дописувачі часопису порівнюють стан освіти «американської України» 3 Галичиною і визначають, що галицькі русини більше дбають про свою культуру. У своїх настановах і закликах до народу автори наголошують: «залиште всякі свари, візьміться до мудрої і доброї народної справи, закладайте руські школи, навчайте дітей вашій рідній мові, пригадуйте їм славну руську історію. Майте дома руську газету та книжечки, закладайте читальні, беріть собі за приклад досвід других просвічених народів. Намагайтеся ублагороднити і приукрасити не тільки тіло, але й розум і серце: розум - наукою, а серце - благородними почуттями братньої любові і згоди. Навчайтеся шанувати один одного і не ображати глупими словами». Заклики «свободівців» не залишалися без уваги. Прогресивні зміни, дійсно, пришвидшили діяльність «Руського Народного Союзу». У квітневому випуску 1894 року «Свобода» звітує про відкриття в Шенандорі русинської школи і читальні, про поширення серед населення русинської абетки. У місті Кармель намаганням священника Костянкевича закладено читальню і школу для старших дітей. У Пітсбурзі отче Полянський заснував руську школу і сам там навчає дітей грамоті. В Шамокині і Олефанті вже діяли руська школа, читальня й оркестр $[11,1]$. Автори звертаються: «Чого нам треба? Клюби такі повинні б, щоб обговорювати і агітувати за такими справами як: утворення вечірньої школи (публічної, на кошт міста), доцільно б для наших людей мати своїх вчителів, утворення безоплатної школки для наших дітей від 6 років, також на кошт міста. В школці такій діти привчалися би англійської бесіди, приготовлювались би до школи висшої та не були б такі дикі» $[16,1]$.

Велика увага приділялася боротьбі за збереження мовної ідентичності українців. Автори постійно зверталися до проблематики мовної денацифікації, особливо русифікації населення. Головним об'єктом аналізу став імперський Емський указ 1876 р., яким «заборонено більш ніж для 20 млн українського народу вживання своєї рідної мови в школах і в письмі» $[17,2] .3$ глибоким співчуттям звертаються автори до «наших рідних братів», обурюючись і запитуючи: 
«Чому? Чи може цивілізований народ пійти проти живого народного слова на порозі XX століття». Дописувач зазначає, що до 1847 р. українські книжки не зазнавали такої цензури. Першопричиною збільшення утисків на українську літературу автор вбачає в діяльності братства св. Кирила і Мефодія. Братство несло загрозу існуванню імперії і «з тої пори з боку цензури почалися дуже сумні часи. Обставини трохи змінилися зі звільненням селян, але вже з 1863 р. десять років малоруські книжки майже не друкувалися» $[17,1]$.

Неодноразово звертається увага на неможливість і небажання українців отримати вищу освіту в Америці. Але, водночас, автор досить критично ставиться до американських вишів і обурений, що в Америці існують так звані «фабрики докторів». В Ілінойсі та Чикаго утворилися «університети», в яких не існує ні професорів, ні студентів. «Якийсь дурисвіт купує у влади дозвіл на відкриття університету і тягне з народу зиски шляхом продажу ступеней докторських, професорських, адвокатських. Велика проблема, коли лікар, маючи такий диплом, починає лікувати людей, осідає десь у провінції та легковірних і неосвічених посилає „на той світ” своїм лікуванням» $[17,2]$.

Окрім просвітництва автори часопису велику увагу приділяли й іншим соціальним аспектам. За даними дослідниці Т. Панфілової, «боротьба з пияцтвом стала загальнонародною справою як з національним лихом. У Галичині було 23269 корчем і шинків. На одну корчму припадало 233 душі, 20 літрів випитої горілки. Пияцтво звело українське село до упадку, а селян - до отупіння. Заборгованість українських селян становила понад 22 мільйони гульденів. Селяни щороку сплачували заборгованість у розмірі 6663 гульдени, або 60 \% майна. Саме за цих трагічних обставин пролунав тривожний голос греко-католицької церкви. 1874 р. митрополит Йосиф (Сембратович) звернувся до народу з посланням «О великім достоїнстві чоловіка». Це послання сучасники назвали «початком справжнього культурного й економічного пробудження нашого села» [6, 28-29].

Автори наголошують, що їх обов'язком $\epsilon$ не тільки спрямовувати народ на добре і корисне, а і «хоронити його від недоброго, шкідливого, щоб злого хоронився, уникати способностей, що можуть зробити нещасливим» $[9,1-2]$. Все, що людина вживає, то гріховно. Наприклад, стосовно їжі автори давали поради про те, що «людина мусить їсти, щоб жити і мати силу до праці. Але коли перебере міру і так наїсться, що аж горлом вертає, а брюхо здується, мов гора, то є і часом смерть через обжорство, котре $\epsilon$ великим гріхом і прєступлєнієм перед натурою і Богом». Як сумний приклад наводиться випадок смерті від обжорства Франка Мартина з міста Данкан штату Оклахома, який пішов до ресторану і там найперше випив 20 склянок пива, потім з'їв 4 фунти м'яса, порцію велику риби, пару фунтів хліба 3 маслом, а наприкінці випив ще 5 горняток кави. 3 цим запасом 
їжі у шлунку пішов додому й опівночі помер. «Через пияцтво стає велика біда через піяньство пойшли найкрасши поля, грунта, будинки, красна худоба в руки плюгавих жидов. Через піяньство родичей пішли діти в невірки: сестра за мамку до жидовських дітей, а брат за жидовского наймита» $[9,2]$. Пияцтво зпустошило села й осади, бо бідні діти лишають батьківську землю, заставлену у жида, i йдуть в далекі краї за море, задля заробітку. «Свобода» подносить свій голос і кождому кричить до вуха: стережись піяньства, єслі не хочеш бути в том життю жебраком, а по смерті в смолі пекельной пражитись на вік». Автор збурений, що через пиятику русини марно втрачають великі кошти, які б могли вкласти в освіту і розвиток своїх дітей або принести до церкви. «Подивись, п’янице, над якою ти пропаст'ю стоїшь! Іди до церкви та спознаєш твоя прежній блуд ... помянешь «Свободу», бо будешь свободний от гріха, будешь свободний от довговь, будешь свободний от гарешту, будешь свободний от непотребних видатков на суд. Свободна буде твоя душа, твоя совість, твой розумь!» $[9,1-2]$.

Русинське духівництво пильно слідкувало за поширенням епідемій і хвороб серед населення, висвітлювало на своїх шпальтах проблеми, пов'язані з охороною здоров'я. Занепокоєння викликало поширення холери, грипу та інших хвороб. У січневому випуску 1897 р. автор поширює інформацію про виникнення нової хвороби - грипу, яка несе загрозу мешканцям Пітсбурга і може привести до смерті: «у нас появилась хвороба, так звана грипа, на котру много людей умирає» $[10,2]$. Поширення різних хвороб в інших країнах теж ставало предметом занепокоєння авторів часопису. Велику увагу духівництво приділяло розповсюдженню чорної віспи в Угорщині та Румунії. I це було недаремно, адже спалахи хвороби фіксувалися на кордоні з Галичиною і призводили до масових смертей молоді $[14,2]$. Червневі випуски «Свободи» 1894 р. давали тривожну статистику щодо розповсюдження холери на русинських землях. Особливо наголошувалося на поширенні холери на землях Східної Прусії та Австрії. Наприклад, у Заліщиках (зараз Тернопільська область) від холери померло 38 осіб. «Дуже сумні вісті доходять з Галичини о появівшейся там холери. Один лікар 3 Заліщиків пише так: не дасть ся описати, з якою скоростію умирають люди, поражені холерою. Тут тільки захворів, а вже по годині везуть до гробу. Місто Заліщики пусткою стоїть. Всяка робота утихла. Багато виїхали, щоб утіч перед тим страшним ворогом. Живемо нині в час холери, де кожний вставши рано не знає, чи вечора дождеться. Люди уже говорять між собою про скорий кінець світу і страшний суд» $[12,3]$. Також під масовий вплив цієї хвороби потрапив Краків і його передмістя. У випуску «Свободи» від 26 вересня 1894 р. надано сумні відомості щодо поширення холери на західноукраїнських землях: у Галичині за тиждень захворіло понад 400 осіб, 200 з яких померло. На Буковині за- 
хворіла 21 особа, померло 16 [13, 3]. Однією з причин розповсюдження епідемій автори вважали антисанітарію і відсутність людських умов у плані гігієни. Здебільшого бідне населення не має можливості часто відвідувати баню, не кажучи вже про можливість мати власні пристойні умови задля відправлення гігієнічних потреб. Одним зі своїх завдань «свободівці» вважали зведення публічної безоплатної купальні для всіх людей. «Чистота - то половина здоров’я. Кожна людина повинна бодай раз на тиждень скупатися, бо тоді був би здоровіший i обминула б його тоді хвороба» [16, 2].

Окрім того, духівництво ставило за мету боротьбу з недоїданням і голодом, висвітлювалися статистичні дані та трагічні випадки голодних смертей серед емігрантів у різних штатах. Наприклад, у тому ж номері часопису було описано випадок смерті трьох людей від голоду через відсутність стабільного заробітку. Чоловік помер від отруєння смердючою рибою, яку знайшов на смітнику, бо не було грошей купити нормальну їжу. Від голоду померла трирічна дівчинка, тому що у батьків не було жодного центу на їжу.

На думку автора, часопис «Свобода» мав досить прогресивний формат видання. 3 огляду на те, що авторами і засновниками газети було духівництво, видання майже позбавлене проповідництва, поширення догматизму і канонічності саме католицької церкви. Часопис мав більше «світську місіонерську» спрямованість на відміну від церковних періодичних видань материкової України. Передостання шпальта часопису містила велике розмаїття різної інформації - від віршів та художніх творів до анекдотів і жартівливих шаржів. А останній аркуш «Свободи» завжди був присвячений розповсюдженню корисної економічної, пізнавальної, торгівельної, рекламної інформації: анонси, афіши, оголошення про роботу, видавання допомоги та книжок, відкриття клубів, аптек, безкоштовні курси, приймальні години лікарів тощо.

Автори не виказували жодних ознак міжконфесійної ворожнечі чи протистояння. Навпаки, з однаковим сумом і обуренням визначали проблеми селянства і робітничого класу як підросійських українських земель, так і австро-угорських; як проблеми православної церкви, так і греко-католицької. Але заради справедливості необхідно відзначити чіткий антисемітський курс часопису. Автори вважали «жидів» винними у всіх можливих і неможливих гріхах і негараздах, що випали на долю українців. Католицьке духівництво навіть толерантніше ставилося до полігамних шлюбних стосунків американських мормонів, ніж до діяльності іудейських громад у США $[16,3]$.

Отже, грунтовний аналіз публікацій українського часопису «Свобода» XIX початку XX ст. відіграв провідну роль греко-католицького духівництва у висвітленні і вирішенні соціальних проблем русинського населення Америки. Часо- 
пис мав вагомий політичний вплив через діяльність єдиного національно-політичного центру українських емігрантів «Руського Народного Союзу». Особливо продуктивною можна вважати діяльність «свободівців» у питаннях поширення просвітництва, відкриття українських шкіл і читалень. Головною метою часопису було збереження української мови, національних традицій та боротьба за українську національну ідентичність.

\section{Abstract}

The purpose of the study is to analyze the impact of Catholic clergy on the social life of the Ruthenium population in America by examining the publications of the Ukrainian journal "Freedom" of the 19th-early 20th centuries. Research methodology: principles of systematic scientific history, use of scientific methods of analysis, synthesis, generalization and comparison. Scientific Novelty and Originality: Through a Detailed Analysis of the Publications of the Ukrainian Freedom Magazine in America in the Nineteenth - Early Twentieth Century's. The author defined the exceptional role of the Catholic clergy in shaping the social values of the Ruthenium people in emigration USA and Canada. Outline of research materials. The most important factor in the social life of Ukrainians in exile was the Ukrainian-language press. The Catholic clergy sought to control the social life of «Ukrainian Americans» in order to preserve national traditions, language, promote enlightenment, organize social assistance for Ukrainians, and highlight the most important problems of immigrants. Authors and contributors to Svoboda called for other peoples (Poles, Czechs, Romanians) to set up grassroots organizations to support entrepreneurship, schooling and education, developing national spirituality and language. Much attention was paid to the participation of the Ruthenian people in political life, the establishment of clubs and cultural centers. The main achievement of the "freedmen» was the creation of a single socio-political emigrant centerthe Russian People's Union. The clergy fought to preserve the linguistic identity of Ukrainians. The authors have constantly addressed the issue of language denationalization, especially Russification of the population. In addition to education, the authors of the journal paid great attention to the analysis of the epidemiological situation, the spread of hunger, methods of combating smallpox, cholera, influenza. Conclusions: The Catholic clergy became an important and almost sole factor in the socio-political life of Ukrainians abroad in the process of national revival and the struggle for national unity and identity.

Keywords: Catholicism, Ruthenium, Liberty magazine, emigration, social.

\section{ДЖЕРЕЛА ТА ЛІТЕРАТУРА}

1. Бачинський Ю. Українська еміграція в 3’єднаних Державах Америки. Львів, 1914. $495 \mathrm{c}$.

2. Біловус Л. І. Україномовна періодика у національно-культурному житті української діаспори США (1991-2017 рр.). Тернопіль: ТНЕУ, 2017. 608 с.

3. Герегова С. Становлення української преси у США (до 120-річчя заснування часопису української громади «Свобода»). Питання історії України. Чернівці. 2013. Т. 16. С. 96-101.

4. Животко А. Нариси історії української журналістики. Подєбради, 1937. 112 с.

5. Качор А. Роля духовенства і церкви у відродженні Західної України. Вінніпег: Накладом Української Вільної Академії, 1999. 31 с. 
6. Панфілова Т. Роль Греко-католицької церкви та їі духовенства у формуванні й діяльності структур громадянського суспільства Галичини (XIX-XX ст.). Історичні студї Східноєвропейського національного університету імені Лесі Украӥнки. Луцьк, 2014. Вип. 11-12. С. 24-30.

7. Свобода. 1893. № 3.

8. Свобода. 1893. № 4.

9. Свобода. 1893. № 6.

10. Свобода. 1894. № 1.

11. Свобода. 1894. № 13.

12. Свобода. 1894. № 23.

13. Свобода. 1894. № 33.

14. Свобода. 1894. № 6.

15. Свобода. 1894. № 9.

16. Свобода. 1899. № 2.

17. Свобода. 1899. № 3.

18. Хімяк О. Українська преса на американському континенті (кінець XIX - початок XX ст.). Українська начіональна ідея: реалії та перспективи розвитку: Зб. наук. пр. Львів, 2012. Вип. 24. С. 27-31.

19. Часто П. Вільне слово американської України. Ужгород: TIMPANI; НьюЙорк: Ukrainian Book, 2012. 816 c.

\section{References}

1. Bachynskyi, Yu. (1914) Ukrainska emihratsiia v Ziednanykh Derzhavakh Ameryky [Ukrainian emigration to the United States of America]. Lviv.

2. Bilovus, L. (2017) Ukrainomovna periodyka u natsionalno-kulturnomu zhytti ukrainskoi diaspory SShA (1991-2017 rr.) [Ukrainian-language periodicals in the national-cultural life of the Ukrainian Diaspora of the USA (1991-2017)]. Ternopil: TNEU.

3. Herehova, S. (2013) Stanovlennia ukrainskoi presy u SShA (do 120-richchia zasnuvannia chasopysu ukrainskoi hromady «Svoboda»). [Formation of the Ukrainian press in the USA]. Pytannia istorii Ukrainy. Chernivtsi. T. 16, 96-101.

4. Zhyvotko, A. (1937) Narysy istorii ukrainskoi zhurnalistyky [Essays on the History of Ukrainian Journalism]. Podiebrady.

5. Kachor, A. (1999) Rolia dukhovenstva i tserkvy u vidrodzhenni Zakhidnoi Ukrainy [The role of the clergy and the church in the revival of Western Ukraine]. Vinnipeh: Nakladom Ukrainskoi Vilnoi Akademii, 9-56.

6. Panfilova, T. (2014) Rol Hreko-katolytskoi tserkvy ta yii dukhovenstva u formuvanni y diialnosti struktur hromadianskoho suspilstva Halychyny (XIX-XX st.). 
[The role of the Greek Catholic Church and its clergy in the formation and activity of civil society structures in Galicia (XIX-XX centuries)]. Istorychni studii Skhidnoievropeiskoho natsionalnoho universytetu imeni Lesi Ukrainky. Lutsk. Vyp. 11-12, 24-30.

7. Svoboda. № 3. 1893.

8. Svoboda. № 4. 1893.

9. Svoboda. № 6. 1893.

10. Svoboda. № 1.1894.

11. Svoboda. № 6. 1894.

12. Svoboda. № 9.1894.

13. Svoboda. № 13. 1894

14. Svoboda. № 23. 1894.

15. Svoboda. № 33. 1894.

16. Svoboda. № 2. 1899.

17. Svoboda. № 3. 1899.

18. Khimiak, O. (2012) Ukrainska presa na amerykanskomu kontynenti (kinets XIX pochatok XX st.) [Ukrainian press on the American continent (end of XIX-beginning of $X X$ century]. Ukrainska natsionalna ideia: realii ta perspektyvy rozvytku: Zb. nauk. pr. Lviv. Vyp. 24, 27-31.

19. Chasto, P. (2012) Vilne slovo amerykanskoi Ukrainy. [Free word of American Ukraine]. Uzhhorod: TIMPANI; Niu-York: Ukrainian Book.

УДК 94:336-057.19(477)»1920»

\section{МАТЕРІАЛЬНЕ ЗАБЕЗПЕЧЕННЯ БЕЗРОБІТНИХ В УСРР У 1920-Х РР.}

\section{Прилипко Руслан}

У статті проаналізовано організаційні заходи радянсько-партійного керівництва із запровадження сочіального страхування від безробіття в період НЕПу. Охарактеризовано порядок виплати допомоги безробітним, зазначено ї̈ розмір та тривалість забезпечення. Висвітлено діяльність бірж праці та страхових органів щзодо призначення матеріальної допомоги. Простежено стан виплати та динаміку розподілу допомоги безробітним серед різних професійних груп. У результаті дослідження автор приходить до висновку, щьо перехід до нової економічної політики, який супроводжувався скасуванням трудової повинності та відкривав нові механізми регулювання ринку прачі через співвідношення попиту та пропозииії на робочу силу, позначився масовим безробіттям. Окрім кон'юнктури ринку на зростання чисельності безробітних суттєво вплинули: зменшення обсягу державної промисловості та слабкий розвиток ї̈ приватної сфери; механізація виробниџтва; військова демобілізація; аграрне переселення, пролетаризація міст тощо. Поряд з індустріальними робітниками, щзо втратили заробіток через згортання виробництва, у групу ризику потрапили некваліфіковані робітники, серед яких вагома частка припадала на жінок та молодь. 